\title{
OPTIMIZING TEACHER COMPETENCE TOWARDS IDEAL AND QUALITY EDUCATOR IN ISLAMIC SCHOOL

\author{
Muthoifin
}

Department of Islamic Education, Universitas Muhammadiyah Surakarta Indonesia.

Email: mut122@ums.ac.id

Article History: Received on $14^{\text {th }}$ March 2020, Revised on $28^{\text {th }}$ August 2020, Published on $21^{\text {st }}$ September 2020

\begin{abstract}
Purpose of the study: This study aims to determine the characteristics of ideal and quality teachers who pass the teacher competency test, teacher problems, teacher's efforts in implementing learning, and the role of the principal in optimizing competencies to create ideal educators.

Methodology: This research is field research with a qualitative type using two methods in the data collection process, namely questionnaires and documentation. The research was conducted at MI Muhammadiyah Kartasura Surakarta.

Main Findings: Ideal and quality teachers are teachers who pass the professional competency test, which includes mastery of material, structure, concepts, and scientific mindsets that support the subject taught and sustainably develop professionalism through reflective action. While the efforts made are optimizing the use of various learning methods and media, as well as providing reinforcement or appreciation to students who ask or answer questions. The role of the principal in optimizing ideal teacher performance is to try to find solutions so that the learning process runs smoothly following the learning plan that has been made so it does not bring disadvantages to students.
\end{abstract}

Applications of this study: this research is expected to be applied in schools, universities, and the wider community that focuses on education issues and the quality of teachers and teaching, as well as competence and certification.

Novelty/Originality of this study: this study focuses on discussing problems, characteristics, concepts, and guidelines for optimizing teacher competence towards ideal and quality educators at MI Muhammadiyah Kartasura Surakarta and combined with the theory of ideal and professional teacher concepts according to the national education system in Indonesia.

Keywords: Ideal Educator, Optimization, Teacher Competence, Islamic School, Quality.

\section{INTRODUCTION}

Teacher's problems, competence, certification, and incentive allowances have always been an interesting issue in the education milieu, from a great amount of allowance to the issue of some of the teachers who pursue certification in order to earn benefit allowance from the government. Certainly, it is a big problem that must be resolved so that the teachers become competent and professional teachers. To take the further step, the Indonesian government through the Directorate General of Teachers and Education Personnel of the Ministry of Education and Culture of Indonesia has focused its interest on the issue of teacher certification, as a step to form a model for examination and selection to increase teacher competence. (Chang, 2017)

A source from the directorate general of teachers and education personnel state that from approximately 1.6 million teachers taking the Teacher Competency Test, 1.3 million teachers have a competence score of zero to six, thus optimization in enhancing the quality of teachers is necessary to solve the problems of competence and teacher certification. In fact, according to the source, there are many teachers who attempt to earn certification in the wrong way. Not to mention, the proliferation of fake diplomas worsens the complexity of this problem. (Surya, 2012)

According to the source of the directorate general of teachers and education personnel, this year the quota for teacher certification is 70,000. However, so far, only 63,000 teachers have fulfilled the requirements, which explains around 7,000 teachers are not eligible for certification. This problem arose since 7000 teachers did not pass the certification test. It is the responsibility of the government to immediately find a solution, review, and continuously re-review the results of teacher competency tests. If there are less qualified teachers, the ministry will provide guidance for them. As of now, the government is still looking for effective components to deal with this problem. It proofs that teacher certification is widely discussed by the Indonesian people and is an interesting issue to be studied. Moreover, the teacher certification program is an effort to improve teacher performance and increase teacher professionalism. (Fahmi et al., 2014)

Professionalism refers to an individual who holds a profession or a term used for someone's appearance in creating work according to one's profession. (Fahriany, 2014) According to the Teacher and Lecturer Law, teachers are professional educators with the main task of educating, teaching, guiding, directing, training, assessing, and evaluating students in early childhood education through formal education, primary education, and secondary education. Teacher tasks as a profession include educating, teaching, and training. Educating implies passing on and developing values. Teaching denotes developing knowledge and skills in the student. Humanity demands teachers act as subsidiary parents in the school environment. They receive sympathy so that they become an idol among their students. Any lesson taught should be able to motivate students. (Rahman, 2016) 
The teaching profession is frequently discussed, almost in all mass media, both electronic media and print media discuss the nobility of the teaching profession and evident life of the teacher. Many people disrespect the teaching profession, oftentimes teachers become the scapegoat of parents if their children fail in tests or do not achieve what they desire. (Surya, 2016)

There are various ways for teachers to improve their professionalism, for instance, to increase professional competence through teacher certification. The purpose of certification is to determine the feasibility of teachers in carrying out their duties as learning agents, improve teacher professionalism, improve educational processes and outcomes, and accelerate the realization of national education goals. (Sparrow, 2018) In that way, one can understand to become professional a profession is required to have intellectual qualities and skills based on the quality standards approved by the institution and is readily prepared to be accountable for the work in a professional manner. Currently, a professional attitude is known as professional management, thus a professional teacher is a teacher who applies the concept of professional management in carrying out life activities, and vice versa, if a teacher does not apply the concept of professional management, it shows that the teacher is not professional. There is a relationship between professionals and professions in the context of work. Professional work is supported by a certain in-depth knowledge that can only be obtained from adequate educational institutions so that their performance is based on the knowledge which can be scientifically justified. (A. A. G. Agung et al., 2017)

Teacher certification is not only aimed at obtaining certification but is also expected that teacher performance will be better and the goals of national education will be achieved. Certified teachers can be professional teachers, teach well, develop their knowledge, and show the excellence of the teaching profession so that the teaching profession will be more valued and well-regarded. (Irmawati et al., 2017)

Teacher competence program has a strategic role in the field of education, even other adequate educational resources are often considered insufficient if they are not accompanied by the adequate quality of teachers. Otherwise, if quality teachers are not empowered by other adequate supporting resources, it may cause less optimal performance. Therefore, teachers are at the forefront of efforts to improve the quality of service systems and educational outcomes. In many cases, the quality of the education system as a whole is related to the quality of teachers. In this way, the significance of improving the quality of education must be carried out simultaneously through efforts to improve the quality of teachers. (Wats \& Wats, 2009)

Besides, the teacher is also a profession so the process of validating professionalism needs to be done. So, an individual who will become an accountant must attend teacher professional education. In Indonesia, efforts are made to make changes and improvements to the quality and level of teachers, such as stipulating Law Number 14 of 2005 on Teachers and Lecturers (UUGD) in December. Article 1 point (11) UUGD states that certification is the process of provision certificate to teacher and lecturer. Based on logic, obviously, the person granted is proven to have mastered two required aspects (minimum educational qualification and mastery of teacher competencies). (Triyanto, 2012)

Based on the background above, the discussion about conceptions, characteristics, problems, and optimizing teachers needs to be researched so that in the future teachers become truly ideal, professional, competent, and qualified teachers.

\section{LITERATURE REVIEW}

The teacher in the education field is an essential element. The position and status of teachers can be seen in various dimensions, namely teachers as individuals, teachers in the family, teachers in schools, teachers as members of society \& citizens, and teachers as servants of Allah. In the perspective of Islam, according to Ahmad Tafsir, education in Islam is any person who is responsible for student development. The task of educators in the perspective of Islam, in general, is to educate, which attempts to develop all potentials in students, both psychomotor, cognitive, and effective. Educators in the family are parents and educators in schools are teachers. (Muthoifin, 2016)

Teachers are professional educators with the main task of educating, teaching, guiding, directing, training, assessing, and evaluating students in early childhood education through formal education, primary education, and secondary education. (Muflih, 2014) By considering a teacher as a professional position, the teacher's duty is no longer only to provide lessons in the classroom during class hours, but also to: a. Plan a learning program; b. Manage the learning process; c. Assess the learning outcome; d. Identify various problems during the learning process; and e. Improve the learning program, provide assistance, and guidance to students outside of class hours. (Kusumawardhani, 2017)

\section{Teacher as Professional}

Professional is a job or activity that is carried out by a person and becomes a source of income that requires expertise or skills that meet certain quality standards or norms and requires professional education. (Claramita, 2016) The teacher is a professional position. The criteria for a professional position include that the position involves intellectual activity, has a specific body of knowledge, requires long preparation to hold it, requires training in a sustainable position, is a permanent career and membership, determines standards of behavior, emphasizes service, has a professional organization and has a code of ethics that is adhered to by its members. (Muthalib, 2012) 
Nowadays, teachers are required to be able to design and choose the accurate learning materials, learning strategies that are according to different student backgrounds, manage learning in an attractive way, select and use learning media that support learning goals, and design evaluations that are based on educational goals oriented towards competence mastery. As a professional position, a teacher position requires further education and special training, namely a bachelor's plus. (Siddik et al., 2017)

To ensure teacher professionalism as a special job, the Teacher and Lecturer Law establishes professional principles as follows: a. Have talents, interests, wake-up call, and idealism, b. Have a commitment to improving the quality of education, faith, devotion, and noble character, c. Have suitable academic qualifications and educational background with the field of work, d. Have the required competencies in the field of work, e. Have responsibility for the implementation of professional duties, f. Earn income determined based on work performance, g. Have the opportunity to develop professionalism sustainably through long-life learning, h. Have guaranteed legal protection in carrying out professional duties, i. Have a professional organization that has the authority to regulate matters related to teacher professional duties. (Ministry of Education and Culture, 2016)

\section{Teacher competence}

Teacher competence is the process of provision of the certificate to the teacher. Teacher certificates are granted to teachers who have met teacher professional standards. Professional teachers are an absolute prerequisite for creating quality education systems and practices. The main basis for the implementation of certification is Law Number 14 of 2005 on Teachers and Lecturers (UUGD) which was stipulated on December 30, 2005. The article stating so is Article 8: Teachers are required to have academic qualifications, competencies, teacher certificates, are physically and mentally healthy, and have the ability to realize the goals of national education. Another article is article 11, paragraph (1), which states that educator certificate as stipulated in Article 8 to be given to teachers who have met the requirements. Another legal basis is Law Number 20 of 2003 concerning the National Education System, and the Regulation of the Minister of National Education Number 18 of 2007 on Certification for Teachers in Position which was stipulated on May 4, 2007. (Ministry of Education and Culture, 2016)

The following are the objectives of teacher certification: a. Determine the feasibility of teachers in carrying out their duties as learning agents and realizing the goals of national education, b. Improve the process and quality of educational outcomes, c. Increase the dignity of teachers, d. Increase teacher professionalism, e. The benefits of teacher certification are detailed as follows, f. Protecting the teaching profession from incompetent practices, which may damage the image of the teaching profession, g. Protecting society from unqualified and unprofessional educational practices, h. Improving teacher welfare. (Ministry of Education and Culture, 2016)

\section{Problems with Teacher Certification}

The prerequisite for passing certification as a benchmark of teacher professionalism invites all elements of society to discuss it. Various problems arise, both problems related to the implementation process and problems related to the quality of the teachers themselves.

The initial idea of certification is to improve the overall quality of education based on Law Number 14 of 2005 on Teachers and Lecturers which stipulates qualifications, competencies, and certification as an integrated effort to empower teachers. Therefore, this program should not be perceived as merely enhancing the welfare of teachers, but rather to improve the competence of the teaching profession. Therefore, this process must be carried out thoroughly and carefully so as not to reduce the quality of teachers. (Musfah, 2011)

However, in reality, many teachers have been certified but their performance does not show any changes (teacher professional competence has not improved). Even Indonesia's 6th President Susilo Bambang Yudhoyono criticized teacher performance. According to him, the quality of teachers in Indonesia must be improved. In fact, he criticized due to too many teachers who passed the certification, as consequence, the majority had received professional and benefit allowances, thus their welfare had bettered but based on input coming, their performance had not changed. (Sukasni \& Efendy, 2017)

Moreover, the president also posed three corrections to teachers in Indonesia: a. The first correction is that there were many complaints and input from various parties regarding the performance of teachers, which had not changed much even though they had passed certification, received allowances, and had a more prosperous life, $b$. The second correction, teachers should be aware of managing the school to be discipline, better, and well-ordered to build students' characters but these qualifications had not been fulfilled, c. The third correction is the President criticized teachers who could not become role models for their students.

The three corrections by President Susilo Bambang Yudhoyono reflect the real practice. Certified teachers should carry out their duties as a professional position. Teacher's task is no longer only to provide lessons in class during lesson times but also includes planning learning programs, managing the learning process, assessing the learning outcomes, diagnosing various problems found in the learning process, improving learning programs, and providing assistance and guidance to students outside of lesson times. (Effendy \& Pertiwi, 2012) 
As in practice, there are many teachers found as those mentioned above, especially certified teachers. For example, teachers rarely make lesson plans and syllabus, the teaching-learning process is not aligned with the applicable curriculum and is not in accordance with the field of study, teachers cannot become role models for students, and researchers also often find teacher absenteeism cases. It should be noted that not all certified teachers show decreased or unchanged performance. Despite all the cons, many certified teachers become professional teachers. Generally speaking, the problem of teacher certification in Indonesia is that the teacher certification program concerns more on the welfare aspects of teachers than improving their quality/performance. (Muthoifin \& Nuha, 2016)

Concerning study on teachers and competence, according to Dwi, the objectives in the teacher certification program are: (1) to determine the feasibility of teachers in carrying out their duties as learning agents in realizing national learning objectives, (2) to improve the process, quality, and educational outcomes, (3) to improve the dignity of teachers, and (4) to increase teacher professionalism in education. According to Muslich, "the aim of teacher certification is to improve the quality of education and increase teacher's welfare". In line with that, according to Farah, teacher certification aims: (1) to protect the teaching profession and education personnel, (2) to protect the community from incompetent practices, (3) to assist and protect education providers, (4) to build public image of the teaching profession and educational personnel, (5) to provide solutions in order to improve the quality of teachers and educational staff. (L. Agung, 2018)

Teacher competence must be viewed as a continuous process. In this process, education includes upgrading, guidance from professional organizations and workplaces, community appreciation for the teaching profession, enforcement of professional code of ethics, certification, teacher quality improvement, rewards, collective determination of individual professional development, including teachers. In the PAT Journal (2001) it is explained that in England and Wales to improve teacher professionalism the government began to pay attention to the balance payment between teacher salaries and their workloads. In the United States, this has been in effect for a long time so it is not surprising that education in the United States has become a model for third countries. In Indonesia, it experienced this process during the Dutch colonial era. After entering the New Order, everything changed so that the impact can be seen now; the teaching profession is at the bottom of the list compared to other professions such as a doctor, prosecutor, and others. (Bambang Sumardjoko, Sudarno Shobron, Muthoifin, 2020)

Table 1: Teacher Task Objectives and Certification Problems

\begin{tabular}{|c|c|c|c|c|}
\hline Teacher Task & Professional & $\begin{array}{l}\text { Certification } \\
\text { Objective }\end{array}$ & $\begin{array}{l}\text { Certification } \\
\text { Advantage }\end{array}$ & Certification Problem \\
\hline $\begin{array}{l}\text { Planning learning } \\
\text { program }\end{array}$ & $\begin{array}{l}\text { Having talents, } \\
\text { interests, wake-up } \\
\text { call, and idealism; }\end{array}$ & $\begin{array}{l}\text { Realizing the } \\
\text { goals of national } \\
\text { education }\end{array}$ & $\begin{array}{l}\text { Protecting the } \\
\text { teaching } \\
\text { profession from } \\
\text { incompetent } \\
\text { practices }\end{array}$ & $\begin{array}{l}\text { Various complaints from } \\
\text { the public about the } \\
\text { teacher's } \\
\text { performance. }\end{array}$ \\
\hline $\begin{array}{l}\text { Managing the } \\
\text { learning process }\end{array}$ & $\begin{array}{lr}\text { Having } & \text { a } \\
\text { commitment } & \text { to } \\
\text { improving } & \text { the } \\
\text { quality } & \text { of } \\
\text { education, faith, and } \\
\text { noble character }\end{array}$ & $\begin{array}{l}\text { Improving } \\
\text { process } \\
\text { quality } \\
\text { educational } \\
\text { outcomes. }\end{array}$ & $\begin{array}{l}\text { Protecting the } \\
\text { image of teachers } \\
\text { as educators. }\end{array}$ & $\begin{array}{l}\text { Already being certified, } \\
\text { receiving allowances, and } \\
\text { having a prosperous life. }\end{array}$ \\
\hline $\begin{array}{lr}\text { Assessing the } \\
\text { process of } \\
\text { learning outcomes }\end{array}$ & $\begin{array}{l}\text { Having educational } \\
\text { qualifications based } \\
\text { on the field of work }\end{array}$ & $\begin{array}{l}\text { Improving } \\
\text { dignity } \\
\text { teachers }\end{array}$ & $\begin{array}{l}\text { Improving } \\
\text { welfare } \\
\text { teachers }\end{array}$ & $\begin{array}{l}\text { Teachers are not aware of } \\
\text { managing schools to } \\
\text { become more disciplined } \\
\text { and well-ordered. }\end{array}$ \\
\hline $\begin{array}{l}\text { Identifying } \\
\text { problems found in } \\
\text { the teaching- } \\
\text { learning process } \\
\end{array}$ & $\begin{array}{l}\text { Having the required } \\
\text { competence in the } \\
\text { field of work }\end{array}$ & $\begin{array}{l}\text { Increasing teacher } \\
\text { professionalism }\end{array}$ & $\begin{array}{l}\text { Protecting the } \\
\text { public from poor } \\
\text { quality education }\end{array}$ & $\begin{array}{l}\text { Students' character } \\
\text { development has not met } \\
\text { the expected qualifications }\end{array}$ \\
\hline \multirow[t]{3}{*}{$\begin{array}{l}\text { Improving } \\
\text { learning program } \\
\text { and facilitating } \\
\text { students outside } \\
\text { lesson times }\end{array}$} & $\begin{array}{l}\text { Being responsible } \\
\text { and professional }\end{array}$ & $\begin{array}{lr}\text { Determining } & \text { the } \\
\text { feasibility } & \text { of } \\
\text { teachers } & \text { in } \\
\text { learning } & \end{array}$ & & $\begin{array}{l}\text { Teachers cannot become } \\
\text { role models for their } \\
\text { students }\end{array}$ \\
\hline & $\begin{array}{lr}\text { Earning income } \\
\text { based on work } \\
\text { performance }\end{array}$ & & & \\
\hline & $\begin{array}{lr}\text { Having } & \text { the } \\
\text { opportunity } & \text { to } \\
\text { develop } & \\
\text { professionalism in a }\end{array}$ & & & \\
\hline
\end{tabular}


sustainable manner

Having guaranteed

legal protection in

carrying out duties

Having a

professional

organization

according to the

professional tasks

of teachers

\section{METHODOLOGY}

This research is field research, which is research conducted directly in the field to obtain the required data. This research is qualitative - research that produces descriptive data in the form of oral or verbal and behavior that can be observed from the person (subject). There are two techniques of data collection used, those are questionnaires and documentation. Questionnaires obtain in-depth information about the performance of teachers who are certified and pass competency tests at MI Muhammadiyah 1 Kartasura Surakarta as well as obstacles and efforts to improve teacher performance in the learning implementation. The documentation method was employed to find data about problems or variables in the form of notes, transcripts, books, newspapers, magazines, inscriptions, and meeting minutes. This method was used to obtain data on geographic location, the history of the establishment of MI Muhammadiyah 1 Kartasura Surakarta, vision and mission, organizational structure, infrastructure, and teacher conditions. (Williams, 2007)

Data analysis was conducted using inductive thinking patterns, namely collecting data from observations, documentation, and questionnaires. Then, from the three types of data, it is analyzed and conclusions are drawn. In analyzing data, the researchers used data reduction flow, which is simplifying the data as the center of research attention by selecting and sorting the raw data that appear in the field. After reducing the data, the data is presented to draw conclusions. The data presentation is limited as information conclusions that give the possibility of drawing conclusions and taking action. (Muthoifin, 2019)

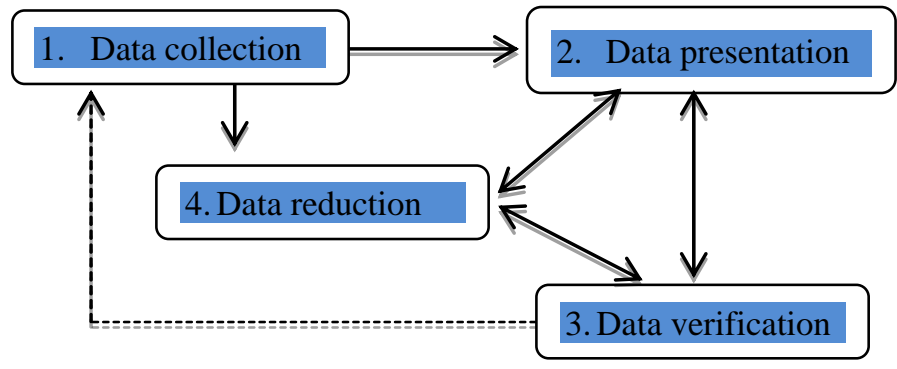

Figure 1: Flowchart of the research phase

\section{RESULTS AND DISCUSSION}

The results of research related to the characteristics of competent teachers at MI Muhammadiyah 1 Kartasura Surakarta are that teachers who are certified and pass the competency test, in the learning implementation, competencies must be possessed by professional teachers are pedagogical competence which is teacher's ability to manage student learning. The mastery of this pedagogic competence consists of: 1) mastery of the students' characteristics, 2) mastery of learning theory and teaching-learning principles, 3) educational learning activities, 4) communication with students, and 5) assessment and evaluation. (Estriyanto, 2016)

\section{Mastery of Student Characteristics}

One of the sub-competencies of pedagogic competence is mastering the student characteristics and aspects of physical, moral, spiritual, social, cultural, emotional, and intellectual. Knowledge of the student characteristics has a fairly important meaning in teaching and learning interactions, especially for teachers in choosing and determining better teaching patterns, which can ensure the smoothness of learning for each student. Given this issue, in making lesson plans apart from curriculum-based, environment, and existing infrastructure, of course, one must take into account student characteristics. In implementing learning in the classroom, teachers must be able to identify the learning characteristics of each student in the class. Teachers try to find out the causes of students' deviant behaviors in order to prevent these behaviors affecting other students. (Arsyad, Safnil, 2016)

Understanding the student characteristics requires a long process because each student has different characteristics and requires meticulousness to be able to understand the characteristics of each student. Understanding student characteristics can be observed when teachers carry out teaching-learning activities in the classroom. Teachers are able to reveal student learning characteristics, intellectual abilities, thinking skills, the socio-economic environment of students, and the learning motivation of each student. (Muthoifin, Nur Hanif Wachidah, 2020) 
Based on the results of research in the learning implementation of certified teachers relating to the student characteristics whether certified teachers could recognize the student characteristics. Not all certified teachers could recognize the student characteristics when they asked about the student characteristics in their classes. Teachers could explain their student characteristics. Based on the results of the research on the learning implementation of certified teachers, they expressed that the majority of certified teachers understood that student characteristics are very important in teaching and learning activities. Teachers did checking to understand student characteristics through the attendance list then observing the physical, both appearance and behavior. During teaching and learning activities, teachers observe students whether they pay attention to the learning process or are being playful. (Halimah, 2017)

Based on the results of research on how the teachers understand the student characteristics in the learning implementation. In the learning implementation, it is important to understand the student characteristics by getting to know the habits of each student in the class, when participating in active or passive lessons or making noise. (Utami, $\underline{2015)}$

\section{Mastery of Learning Theory and Educational Learning Principles}

The success or failure in achieving educational goals merely depends on how the learning process is experienced by students, learning theory and educational learning principles should emphasize students as learning subjects. In the learning process, teachers must organize each teaching and learning activities and respect their students as subjects that have prior knowledge, abilities, and potential within them. In the learning process, teachers must provide more motivation for students to feel passionate about learning so that students are expected to be more active in the learning process. (Cholidian, 2018)

Based on the results of the research on the learning implementation for certified teachers related to the learning method, whether the teachers have mastered learning theory and the educational learning principles. The majority of certified teachers applied various learning strategies, methods, and techniques that are creative in delivering lessons by applying a learning approach and the majority were very good. Regarding the learning process of certified teachers, teachers were good at lesson planning. The methods and media used were also very good. However, when teachers supervised the learning process in the student's active classroom. In addition, the teacher also motivated and provided opportunities for students to express their opinions and ideas. (Haryanto et al., 2016)

Some of the certified teachers were already good. Teachers are good at learning planning, the methods and media used are also good. However, when the teacher carried out the learning process in the classroom, the activeness of students was not optimal. Teachers still were the center of learning, students and teachers should interact with each other or twoway communication so the teacher did not only explain continuously and students only listened and took notes. In addition, teachers must also motivate students and provide opportunities for students to express their opinions and ideas. As seen in the learning implementation, teachers still were more dominant. Teachers continued to explain the material to students and rarely gave opportunities and motivated students to ask questions. (Kanokorn et al., 2014)

Regarding the use of learning methods and media to present material, teachers revealed that in presenting the material they often used the lecture method. Teachers believed that the lecture method would further add and broaden students' insights and knowledge. (Shobron \& Rahman, 2019)

\section{Educational Learning Activities}

The learning objectives will be achieved optimally if teachers can create education learning for students, from not knowing anything to knowing more. Educational learning activities include teachers who can carry out learning activities in accordance with a complete design. Teachers carried out learning activities to help the learning process of students not the otherwise, to test them thus making students feel depressed and respond to mistakes made by students as a learning process, not merely mistakes that must be corrected. For instance, knowing in advance other students who agree/disagree upon the answers before providing an explanation of the correct answers and carrying out learning activities according to the content of the curriculum and correlating them to the daily life context of the students. (Noor \& Suyanto, 2019)

Basically the certified teachers at MI Muhammadiyah 1 Kartasura Surakarta seeks to create educational learning activities. According to the results of research related to how they create educational learning activities in the learning implementation. The majority were already good, certified teachers carried out learning activities in accordance with a complete draft and also used learning aids. (Supriatna, 2005)

\section{Communication with Students}

Communication in the learning process is very important to achieve the learning objectives. At this stage, teachers are required to communicate effectively, empathically, and politely with students during the teaching-learning process in the classroom. Teachers must be able to communicate subject systematically to students. Teachers must pay attention and listen to all questions and responses from students and respond to students' questions attentively. (Franzoni \& Assar, $\underline{2009)}$ 
Based on the results of research on the learning implementation of certified teachers related to communication in the learning process, whether teachers can communicate with students effectively in learning, the majority of certified teachers were already good at communicating with students. When communicating with students, especially in the learning process, teachers must communicate learning material systematically, speak effectively and efficiently with students, display polite and empathic personalities with students. (Surya, 2012)

\section{Assessment and Evaluation}

Assessment of learning outcomes is an activity or method intended to determine the success of learning objectives that have been achieved and the learning process that has been carried out. At this stage, teachers are required to be able to determine the approaches and methods of evaluation, preparation of evaluation tools, implementation, processing. Conducting assessment and evaluation of learning processes and outcomes and utilizing the results of assessments and evaluations for the benefit of learning are important aspects of pedagogical competence. (Sparrow, 2018)

Based on the research results on teachers at MI Muhammadiyah 1 Kartasura Surakarta regarding the assessment or evaluation carried out in the learning process, teachers had carried out an assessment and evaluation of the learning process and results. The majority of certified teachers had carried out assessment and evaluation of learning processes and outcomes. At the beginning of the semester, teachers are required to make a teacher administration which also consists of lesson plans and an assessment system that will be carried out. The evaluations carried out are in the form of post-tests, pre-tests, and individual and group assignments. The written evaluations carried out in one semester include mid-semester and semester tests. For daily and mid-semester tests, remedies/enrichments are provided. All certified teachers show that they had carried out an assessment and evaluation of the learning process and outcomes in schools. (Arsyad, Safnil, 2016)

\section{Teacher Efforts in Increasing Competence and Ideality}

Efforts made by teachers in order to improve teacher competence include: 1) mastery of material structures, concepts, and scientific mindset that support the subjects and 2) continuous professional development by taking reflective action.

\section{Mastery of Material, Structure, Concepts, and Scientific Mindsets}

Before appearing in front of the class to conduct the learning process, teachers must master the materials that will be delivered and, at the same time, materials that support the learning process. By mastering the material, teachers will deliver the subject matter dynamically. Mastering the material, structure, concepts, and scientific mindset that support the subject contains two areas of mastery of the material, namely mastery of subject material as stated in the school curriculum and mastery of other subjects that can enrich and clarify the subject being taught.

The research results of teachers at MI Muhammadiyah 1 Kartasura Surakarta related to the mastery of material structure, concepts, and scientific mindset that support the subjects being taught. The majority of certified teachers mastered the concepts in learning, science education as a means of development for every field of educational development. Also, they mastered the use of learning materials to develop aspects of cognitive, socio-emotional, moral values, and sociocultural. Subsequently, they mastered the subjects being taught. (Daulay, 2017)

Teachers had varied materials that come from various sources and teaching materials. When implementing learning, the teachers could communicate the material systematically and related to conditions in the field.

The results also show that certified teachers mastered the material concept, structure, and scientific mindset that support the subject and could correlate the material with other relevant knowledge. (Novita, 2019)

\section{The Use of Various Learning Methods and Techniques}

One form of applying professional competence is developing professionalism in a sustainable manner by taking reflective action. Developing professionalism in a sustainable manner is by taking reflective action, in which teachers reflect on their performance continuously, for instance, evaluating the results of their performance to improve learning. In the learning implementation, teachers can ask students' opinions regarding teaching methods and the learning process performed by teachers. (Ramdhani et al., 2012)

The research results with teachers at MI Muhammadiyah 1 Kartasura Surakarta show a sustainable professional development through reflective action by certified teachers regarding whether certified teachers use various learning methods and techniques. The majority of certified teachers had used various learning methods and techniques. The use of instructional media depended on the conditions and situation of the class. If the teachers allowed and must have used learning media, it would be useful to assist the teaching-learning process. But in terms of delivering material, teachers often used the lecture method. Teachers preferred the lecture method because by listening to the teachers' explanations, the teachers believe that students will get more knowledge and broad insights than using other methods. Indeed, by using the lecture method, students rarely ask questions or express ideas but they understand better. (Shobron \& Anshori, 2020) Certified teachers participated in various activities or training related to professional development in order to improve performance in the learning implementation as expressed below: "Of course, teachers who are certified and pass the competency test are given the training to develop professionalism, especially in supporting the learning process." 


\section{The Effort of Principal for Optimizing Quality and Competence Improvement of Teachers}

The roles of the principal on teachers who are certified and pass the competency test to overcome obstacles in improving performance in the learning process are as follows: the role of principal on certified teachers in the research shows that Mr. Anwar Sanusi as the Principal of MI Muhammadiyah 1 Kartasura Surakarta became more creative in creating learning media and writing scientific papers. For those who are certified, performance improvement became more active and disciplined, while those who are non-certified teachers were encouraged to increase dedication and loyalty. (Muthoifin et al., 2020) The principal motivated and empowered every teacher to be more creative and innovative in the teaching-learning process through workshops twice a year. At a minimum requirement, teachers who are certified are better in teaching methods and are also better than before being certified. (Syamsul Hidayat, Sudarno Shobron, 2020)

The principal of MI Muhammadiyah 1 Kartasura Surakarta regarding the curriculum development by certified teachers in MI Muhammadiyah 1 Kartasura Surakarta stated that teachers became more discipline in teaching. Handbooks/literature increased. As consequence, certified teachers became more responsible. There is an evaluation for certified teachers. They became more hard-working individuals according to their profession, well-ordered, creative, and innovative. Certified teachers already could develop a curriculum as evidenced by the compiled syllabus according to the curriculum then described it through the learning process plan, as follows: certified teachers had become more orderly in learning administration, each semester teachers collect teacher administration to be checked by the curriculum vice principal and the principal. The development of the curriculum described through the syllabus and lesson plans has considered the principles of curriculum development, including the needs and interests of students, the environment, and responsiveness to science and technology. (Tanang \& Abu, 2014)

Table 2: The characteristics of professional teachers and improving teacher professionalism

\begin{tabular}{llrl}
\hline $\begin{array}{l}\text { Characteristics of Teacher } \\
\text { Professionalism }\end{array}$ & $\begin{array}{l}\text { The effort made by the Teacher in } \\
\text { Improving } \\
\text { Professionalism }\end{array}$ & $\begin{array}{l}\text { The Role of } \\
\text { Increasing } \\
\text { Professionalism }\end{array}$ & $\begin{array}{l}\text { Principals in } \\
\text { Teacher }\end{array}$ \\
\hline $\begin{array}{l}\text { Mastering the Characteristics of } \\
\text { Students }\end{array}$ & Mastery of material structure & $\begin{array}{l}\text { More collaborative in making } \\
\text { learning media and }\end{array}$ \\
\hline $\begin{array}{l}\text { Mastering Learning Theory and the } \\
\text { Principles of Educating Learning }\end{array}$ & Mastery of material concepts & $\begin{array}{l}\text { More collaborative in writing } \\
\text { scientific papers }\end{array}$ \\
\hline Educating Learning Activities & $\begin{array}{l}\text { Certified teachers using varied } \\
\text { learning methods. }\end{array}$ & $\begin{array}{l}\text { It stated that teachers more } \\
\text { diligent in teaching. }\end{array}$ \\
\hline Communication with Students & $\begin{array}{l}\text { Certified teachers using varied } \\
\text { learning techniques. }\end{array}$ & $\begin{array}{l}\text { Handbooks or literature with lots } \\
\text { of colors }\end{array}$ \\
\hline Evaluation and Assessment & $\begin{array}{l}\text { Certification teachers have carried } \\
\text { out assessment and evaluation of } \\
\text { learning processes and results }\end{array}$ & $\begin{array}{l}\text { Work hard according to his } \\
\text { profesion, discipline, curriculum, } \\
\text { and initiative }\end{array}$ \\
\hline
\end{tabular}

\section{CONCLUSION}

The concept of competent and ideal teachers at MI Muhammadiyah 1 Kartasura Surakarta had mastered the student characteristics to optimize teachers' performance in the teaching-learning process in the classroom. Thus, teachers in schools have mastered learning theory and learning principles but have not been maximized since the learning process is not student-oriented but teacher-oriented.

The teachers could develop a curriculum related to the subject. The certified teachers carried out educational learning activities in the learning implementation. Certified teachers could communicate effectively, emphatically, and politely with students. They also carried out evaluation/assessment learning activities in accordance with evaluation principles and utilized the results of the assessment and evaluation for the benefit of learning.

Competent teachers at MI Muhammadiyah 1 Kartasura Surakarta also mastered the material, structure, concepts, and scientific mindset that support the subjects. Increasing competence through various existing media as a form of continuous professional development was done by taking reflective action. Following motivation, when participating in the learning process, students' activeness in the learning process was still low. Learning facilities and infrastructure are already adequate but the management was not optimal. Eventually, the tools and learning media used by teachers were often damaged and not immediately repaired.

Efforts made by certified teachers to overcome obstacles to optimize performance in the learning implementation at MI Muhammadiyah 1 Kartasura Surakarta used various methods and learning media. In addition, they also appreciated students who asked or answered questions. Teachers attempted to find solutions so the learning process runs smoothly according to the lesson plan previously made so that it did not affect students.

\section{LIMITATION AND STUDY FORWARD}

The implication of this research is expected to become a reference and material for experts working in schools, universities, and the wider community who study education issues and the quality of teachers and teaching, as well as 
competence and certification in order to become ideal and quality educators in Islamic education institutions and national education in Indonesia, so that it can run in accordance with the national education system in Indonesia.

\section{ACKNOWLEDGEMENT}

The researchers would like to thank all the components that support the accomplishment of this research, especially to the rector, director, head of the study program, LPPI (Lembaga Pengembangan Publikasi Ilmiah) in Universitas Muhammadiyah Surakarta.

\section{AUTHORS CONTRIBUTION}

Muthoifin: First author, corresponding author, finishing, article reviewer, editing, and doctor of Islamic education.

\section{REFERENCES}

1. Agung, A. A. G., Gading, I. K., Werang, B. R., Sudiarta, I. G. P., \& Marti, N. W. (2017). Investigating teachers' perception on the importance of teachers' certification and of professional development program in Indonesia: An empirical study from Bali. International Journal of Research Studies in Management, 6(1), 6573. https://doi.org/10.5861/ijrsm.2017.1786

2. Agung, L. (2018). Character Education Integration in Social Studies Learning. Historia: Jurnal Pendidik Dan Peneliti Sejarah, 12(2), 392. https://doi.org/10.17509/historia.v12i2.12111

3. Arsyad, Safnil, I. (2016). the Failure of Certification Program To Unify Indonesian Teachers 'Perception on Teacher Professionalism: the Case of Bengkulu Junior and Senior High-School Teachers Kegagalan Program Sertifikasi Untuk Menyatukan Persepsi Guru Indonesia Tentang Profesio. TRIADIK, 15(2), 43-57.

4. Bambang Sumardjoko, Sudarno Shobron, Muthoifin, P. (2020). Teacher Certification and Professionalism in Indonesia. International Journal of Advanced Science and Technology, 29(8), 640-648.

5. Chang, M. C. (2017). Teacher Reform in Indonesia (p. 15).

6. Cholidian, M. A. (2018). Learning Motivation In Project Based Learning Model Of X Grade Student In Islamic Religious Education Learning In State Senior High School 7 Malang Thesis. In Central Library of UIN Malang (Issue 1). https://doi.org/10.1017/CBO9781107415324.004

7. Claramita, M. (2016). Revealing “Tut Wuri Handayani” - A Student-Centred Learning Approach- by Ki Hajar Dewantara from The Early 20th Century: A Literature Review. Jurnal Pendidikan Kedokteran Indonesia; The Indonesian Journal of Medical Education, 5(1), 1-14. h

8. Daulay, H. P. (2017). Islamic Education In Indonesia: A Historical Analysis of Development and Dynamics. 4th International Conference the Community Development in ASEAN ®2017, 13(2), 291-307. http://mpsi.umm.ac.id/files/file/291_ Islamic Education In Indonesia A Historical Analysis.pdf

9. Effendy, B., \& Pertiwi, M. (2012). Indonesia's Democratic Venture: History, Practice and the Challenge Ahead. Studia Islamika, 19(3). https://doi.org/10.15408/sdi.v19i3.356

10. Estriyanto, Y. (2016). A Review of Indonesian Pre-Service Teacher Certification Policy from the Point of View of the Philosophy of Vocational Education. International Confrence on Teacher Training and Education, 1(1), 245-253.

11. Fahmi, M., Padjadjaran, U., Surabaya, U. N., \& Trust, S. (2014). Teacher Certification in Indonesia: A Confusion of Means and Ends Working Paper in Economics and Development Studies Department of Economics Teacher Certification in Indonesia : A Confusion of Means and Ends Mohamad Fahmi, Achmad Maulana, and Arief Ans (Issue April).

12. Fahriany. (2014). Teacher Education In Indonesia (An Account on the Development and Programs to Improve the Professional Qualification and the Competence of Indonesia Teaching Personnel). Tarbiya, I(1), 1-12. https://doi.org/10.15408/tjems.v1i1.1107

13. Franzoni, A. L., \& Assar, S. (2009). Student learning styles adaptation method based on teaching strategies and electronic media. Educational Technology and Society, 12(4), 15-29.

14. Halimah, D. N. (2017). Improving The Students' Vocabulary Mastery By Using Story Telling ( A Classroom Action Research at the Seventh Grade of SMP Ta'mirul Islam Surakarta in the Academic Year of 2016/2017). In IAIN Surakarta (Vol. 6). IAIN Surakarta.

15. Haryanto, E., Mukminin, A., Murboyono, R., Muazza, M., \& Ekatina, M. (2016). Teacher certification policy in Indonesia: Evidence from certified English teachers at one public high school. Turkish Online Journal of Qualitative Inquiry, 7(3), 224-244. https://doi.org/10.17569/tojqi.31703

16. Irmawati, D., Widiati, U., \& Cahyono, B. (2017). How Do Indonesian Professional English Teachers Develop Their Pedagogical Competence in Teaching Implementation? Arab World English Journal, 8(2), 293-307. https://doi.org/10.24093/awej/vol8no2.21

17. Kanokorn, S., Pongtorn, P., \& Sujanya, S. (2014). Soft Skills Development to Enhance Teachers' Competencies in Primary Schools. Procedia - Social and Behavioral Sciences, 112(Iceepsy 2013), 842-846. https://doi.org/10.1016/j.sbspro.2014.01.1240

18. Kusumawardhani, P. N. (2017). Does teacher certification program lead to better quality teachers? Evidence from Indonesia. Education Economics, 25(6), 590-618. https://doi.org/10.1080/09645292.2017.1329405

19. Ministry of Education and Culture, C. for E. D. and S. and C. (2016). The Management of National Education 
in Year 2014/2015 at a Glance. In Ministry of Education and Culture (p. 124). Division of Utilization and Services. - Jakarta: Center for Educational and Cultural Data and Statistics, MoEC, 2016. http://publikasi.data.kemdikbud.go.id/uploadDir/isi_6549DA84-7A7F-44B5-AD22-829B1F002A4F.pdf

20. Muflih, A. (2014). Leadership Evolution of Salafiyah Boarding School Leader at Lirboyo Kediri. International Journal of Business and Management Invention, 3(3), 34-50.

21. Musfah, J. (2011). Professional Teacher Education (PPG) of Islamic Religious Education (PAI) in Indonesia. Semantic Scholar, 11(2), 10-14. h

22. Muthalib, A. (2012). Islamic Education Research Problem. Journal of Education and Learning (EduLearn), 6(2), 81. https://doi.org/10.11591/edulearn.v6i2.150

23. Muthoifin, Nur Hanif Wachidah, R. A. R. (2020). Contribution of Kartini's Thought on Women Education. Humanities \& Social Sciences Reviews, 8(2), 143-150. https://doi.org/10.18510/hssr.2020.82e18

24. Muthoifin. (2016). Ki Hadjar Dewantara Educational Thought Perspective of Islamic Education. Prosiding ICTEE FKIP UNS, 1, 773-779.

25. Muthoifin. (2019). Shariah Hotel and Mission Religion in Surakarta Indonesia. Humanities \& Social Sciences Reviews, 7(4), 973-979. https://doi.org/10.18510/hssr.2019.74133

26. Muthoifin, \& Nuha. (2016). the Optimization of Local Autonomy Politic for Nation Progress and Synergetic on Islamic Perspective. The 4th University Research Coloquium 2016, 72-79. https://publikasiilmiah.ums.ac.id/xmlui/handle/11617/7679

27. Muthoifin, Nuha, \& Shobron, S. (2020). Education and Leadership in Indonesia: A Trilogy Concept in Islamic Perspective. Universal Journal of Educational Research, 8(9), 4282-4286.

28. Noor, A. F., \& Suyanto, S. (2019). The Analysis of Character Strengthening Strategy based on Teaching of Ki Hajar Dewantara in Industry 4.0. Advances in Social Science, Education and Humanities Research, 335(ICESSHum), 1002-1009. https://doi.org/10.2991/icesshum-19.2019.155

29. Novita, P. (2019). What Happened to Initial Teacher Education in Indonesia? AReview of the Literature. European Journal of Social Science Education and Research, 9563(December), 88-103. https://doi.org/10.26417/ejser.v6i3.p88-103

30. Rahman, A. (2016). Teacher professional development in Indonesia: The influences of learning activities, teacher characteristics and school conditions. University of Wollongong Thesis Collections, 300. https://doi.org/10.1021/jo001549j

31. Ramdhani, N., Ancok, D., Swasono, Y., \& Suryanto, P. (2012). Teacher Quality Improvement Program: Empowering Teachers to Increasing a Quality of Indonesian's Education. Procedia - Social and Behavioral Sciences, 69(Iceepsy), 1836-1841. https://doi.org/10.1016/j.sbspro.2012.12.134

32. Shobron, S., \& Anshori, A. (2020). Method for Developing Soft Skills Education for Students. Universal Journal of Educational Research, 8(7), 3155-3159. https://doi.org/10.13189/ujer.2020.080744

33. Shobron, S., \& Rahman, S. A. (2019). Humanist islam in indonesia ahmad syafii maarif perspective. Humanities \& Social Sciences Reviews, 7(6), 780-786. https://doi.org/10.18510/hssr.2019.76118

34. Siddik, D., Syafaruddin, S., \& Widodo, H. (2017). The Implementation of Education and Training Program of Madrasah Islamic Religion Teacher in Improving Profesionalism Teacher (Case Study at Religious Traning Center Medan). IOSR Journal of Humanities and Social Science, 22(05), 01-09. https://doi.org/10.9790/08372205080109

35. Sparrow, S. M. (2018). Teaching and assessing soft skills. In Journal of Legal Education (Vol. 67, Issue 2).

36. Sukasni, A., \& Efendy, H. (2017). The Problematic of Education System in Indonesia and Reform Agenda. International Journal of Education, 9(3), 183. https://doi.org/10.5296/ije.v9i3.11705

37. Supriatna, A. (2005). Indonesia's Issues and Challenges on Teacher Professional Development. CICE Series, $4(2), 29-42$.

38. Surya, P. (2016). Student Teacher Recruitment in Indonesia: An Initial Step to Promote Teacher Professionalism and Teaching Professionalization. Advances in Economics, Business and Management Research, 14(1), 457-462. https://doi.org/10.2991/icemal-16.2016.94

39. Surya, P. (2012). Reforming Teacher Training For Better Education In Indonesia. 5th International Indonesia Forum, 9-10.

40. Syamsul Hidayat, Sudarno Shobron, E. C. (2020). Pancasila and Communism Perspectives on Islamic Thought. International Journal of Psicososial Rehabilitation, 24(8), 3500-3508.

41. Tanang, H., \& Abu, B. (2014). Teacher Professionalism and Professional Development Practices in South Sulawesi, Indonesia. Journal of Curriculum and Teaching, 3(2), 25-42. https://doi.org/10.5430/jct.v3n2p25

42. Triyanto. (2012). Improving Teacher Profesionalism through Certification Program: An Indonesia Case Study. International Journal of Educational and Pedagogical Sciences, 6(7), 864-868.

43. Utami, I. G. A. L. P. (2015). Teacher Certification Program in Indonesia: Problems and Recommendation for the Betterment of the Program. International Journal of English and Education, 4(2), 471-481.

44. Wats, M., \& Wats, R. K. (2009). Developing soft skills in students. International Journal of Learning, 15(12), 1-10. https://doi.org/10.18848/1447-9494/CGP/v15i12/46032

45. Williams, C. (2007). Research Methods. Journal of Business and Economic Research, 5(3), 65-72. 